\title{
Pielgrzymując do Zabriskie Point - Antonioni i sielanka zWana USA
}

\author{
SŁAWOMIR MASŁOŃ
}

O ileż to lepiej, gdy caly kraj jest ogrodem, a jego mieszkańcy wychowali się w rajskich altanach.

R. W. Emerson, Młody Amerykanin ${ }^{1}$

Pierwszą rzeczą, która prawie zawsze pojawia się w dyskusjach o filmie $Z a$ briskie Point Michelangela Antonioniego (1970), nie jest jego komercyjna porażka, ale to, że został on niemal jednogłośnie uznany za kompletne niepowodzenie przez amerykańskich (i nie tylko amerykańskich) krytyków, nawet takich jak Stanley Kauffmann, którzy do tej pory uważali się za propagatorów Antonioniego. Taka całkowita zgoda w opiniach ludzi o dość różnych przekonaniach estetycznych już sama w sobie jest zastanawiająca, w szczególności jeśli zestawić ją ze znacznie różniącymi się opiniami na temat innych „kontrowersyjnych” filmów tego okresu, takich jak Bonnie i Clyde (Arthur Penn, 1967) czy Swobodny jeździec (Dennis Hopper, 1969). By zilustrować, jak dziwna była ta reakcja komentatorów, wystarczy chyba powiedzieć, że właściwie wszystko w filmie zostało uznane za nieudane przez takiego lub innego krytyka, z jednym ważnym wyjątkiem: zwykle niechętnie przyznawano jednak, że film jest efektowny wizualnie. A zatem, jeśli film Antonioniego nie był bardziej bezsensowny niż na przykład wspomniane wyżej tytuły (a nie był), krytyczna nagonka na Zabriskie Point wydaje się mówić nawet więcej o Ameryce (i jej krytycznym establishmencie) w roku 1970, niż Antonioniemu udało się zawrzeć w filmie.

Film rozpoczyna się od nieostrego obrazu, któremu towarzyszy muzyka perkusyjna zmiksowana z elektronicznie zniekształconymi głosami, z których wyłania się coś na kształt cinéma vérité: w dużym pomieszczeniu grupa różnokolorowych studentów (choć w większości białych) dyskutuje o strajku na kampusie, który został organizowany przez Związek Czarnych Studentów. Uczestnicy spotkania omawiają strategie protestu i - co ważniejsze - brak poparcia większości białych studentów dla strajku. Większość wymiany zdań pomiędzy czarnymi przywódcami strajku a białymi radykałami obecnymi na sali dotyczy różnicy,,egzystencjalnej” między klasową i rasową świadomością czarnych i białych, co dobitnie wyraził jeden z czarnych przywódców, mówiąc do białych: Zajmujecie się rzeczami, które sa $w$ rzeczywistości bez znaczenia (...). Przymykaja cię za trawkę i to robi z ciebie rewolucjonistę. Nie - gdy dostajesz od glin po łbie, gdy wytamuja drzwi w twoim domu, nie pozwalają ci żyć, gdy nie możesz znaleźć pracy, nie możesz pójść do szkoty, 
nie masz co jeść. To właśnie robi z ciebie rewolucjonistę. Kapujesz? Dlatego czarni należa, jak to mówicie, do innej kategorii.

Stopniowo dyskusja staje się coraz gorętsza, ale też coraz bardziej chaotyczna. Ponownie zostaje nadany jej kierunek, gdy jeden z białych uczestników zebrania zadaje fundamentalne pytanie jednemu z czarnych, który opowiada się za walką zbrojną, spodziewając się przemocy ze strony policji: Czy jesteś gotów umrzeć? Na to czarny odpowiada: Czarni umieraja. Wielu czarnych już umarło w tym kraju. Czarni wywalczyli sobie to przywództwo krwia, chłopie, nie zamierzamy z niego zrezygnować. Jest to najpoważniejszy i pełen największego napiecia moment w całej dyskusji, którym ujawnia się pewną prawdę (vérité) - historyczny dowód na niezaprzeczalny rozłam między rasami. Jednak w tym momencie dzieje się coś, co wydaje się przeczyć temu rozłamowi, czyniąc z niego farsę - młody biały mężczyzna wstaje z miejsca i mówi: Té jestem gotów umrzeć. Ale nie z nudów. I opuszcza zebranie. Wkrótce okaże się, że jest to Mark (Mark Frechette), jeden z dwojga głównych bohaterów filmu, a tym, co od początku wyróżnia go z grupy, jest jego deklaracja, że w odróżnieniu od innych białych jest gotów umrzeć także (jak czarni). Jednak ponieważ jest biały, a co za tym idzie - nie doświadczył dyskryminacji i przemocy, które sprawiają, że człowiek staje się prawdziwym rewolucjonistą, jego wypowiedź nie zostaje wzięta poważnie; zostaje potraktowana jako „gadanie” białego. Ten burżuazyjny indywidualizm, któremu ulega, doprowadzi do tego, że zginie - mówi jeden z czarnych przywódców zebrania, automatycznie zakładając, że motywem chęci działania białego musi być indywidualizm, antypolityczna mitologia białych Amerykanów. A ponieważ Mark rzeczywiście zostanie zabity w Zabriskie Point, zmagania pomiędzy historycznym i mitologicznym determinizmem staną się od tej chwili ważnym motywem filmu.

Po opuszczeniu zebrania przez Marka zostaje nam przedstawionych dwoje innych bohaterów, z których każdy jest związany z ważnym wątkiem fabuły. W holu biurowca Sunnydunes Development Co. pojawia się Daria (Daria Halprin), która dorabia sobie, wykonując dorywczo pracę sekretarki. Spiera się z zarozumiałym ochroniarzem, który nie chce jej pozwolić wjechać na dach, gdzie podczas lunchu zostawiła książkę. W tej chwili jeden z głównych decydentów firmy, Lee Allen (Rod Taylor), wysiada z windy i pod wrażeniem atrakcyjności dziewczyny daje jej pozwolenie. Jednak oprócz przedstawienia postaci koniecznych dla dalszego rozwoju fabuły scena ta wprowadza także ważny motyw, który będzie przewijał się dalej w filmie. W holu Sunnydunes ochroniarz siedzi otoczony ekranami pokazującymi, co się dzieje w różnych częściach budynku, a władza, którą reprezentuje, jest przyczyną jego wyniosłości. Jednakże łatwa opozycja pomiędzy obserwatorem, który ma kontrolę, a bezradnym obserwowanym zostaje podważona przez przestrzeń, w której rozgrywa się scena: hol jest salonem luster. Nie tylko ekrany „odzwierciedlają" rzeczywistość biur i korytarzy: tafle szkła, polerowany marmur i inne gładkie powierzchnie holu odbijają ludzi, przedmioty i ich odbicia w nieskończoność ${ }^{2}$. Ludzie, którym wydaje się, że obserwują i tym samym sprawują kontrolę, są w rzeczywistości częścią spektaklu.

Następna sekwencja, w której powracamy do Marka, jest kluczowa, ponieważ dochodzi w niej do określenia wizualnych i konceptualnych ram filmu. Zaczyna się ona od namalowanego obrazu krowy rasy Holstein, który wygląda jak reklama, jednak po chwili zaczyna przesuwać się w lewo i okazuje się wizerunkiem umiesz- 


\section{SŁAWOMIR MASŁOŃ}

czonym na boku samochodu dostawczego. Niespodziewanie okazuje się, że to, co pojawia się za samochodem dostawczym, nie jest widokiem ulicy, ale namalowaną sielankową scenką, na której farmer, stojąc na swym wozie, rzuca jedzenie stadu świń pasącemu się na wielkim zielonym pastwisku otoczonym zielonymi wzgórzami, nad którymi wisi niebieskie niebo. Po przeskoku montażowym do bliższego ujęcia na farmera i kolejnym cięciu kamera zaczyna panoramować w prawo: widzimy więcej trawy i świń, a także czerwony drewniany budynek, słupy energetyczne i linie wysokiego napięcia. Gdy po kolejnym cięciu w końcu możemy zobaczyć, gdzie kończy się mural, a zaczyna ulica (ujęcie, w którym pojawia się również czerwony pickup Marka poruszający się w naszym kierunku), prawdziwe niebo Los Angeles wygląda po prostu na lekko wyblakłą kontynuację nieba namalowanego, a linie wysokiego napięcia (lub ich cienie), które mogliśmy wziąć za część muralu, okazują się prawdziwymi liniami ciągnącymi się wzdłuż jednej z ulic LA. Po chwili jednak, gdy samochód Mark skręca za rogiem, wydaje się, że mamy do czynienia raczej z kontrastem niż kontynuacją - widzimy samochody dostawcze Farmer John's Meats (jednego z największych producentów wieprzowiny w Kaliforni ${ }^{3}$ ), a zatem bukoliczna powierzchnia muralu zostaje przeciwstawiona okrutnej rzeczywistości rzeźni za nią ukrytej. Jednak ten efekt głębi zostaje od razu zdestabilizowany, ponieważ kamera robi gwałtowny najazd na część muralu znajdującego się nad pojazdami, na którym jakiś obdartus (jego wygląd skontrastowany jest z sielankowymi farmerami) kradnie przerażoną świnię. A zatem skoro tylko pojawia się rozróżnienie pomiędzy iluzją (sielanką) i rzeczywistością, od razu zostaje ono ponownie „spłaszczone”, to znaczy przekształcone w iluzję (w sielankową powierzchnię muralu). Jednak ponieważ zaczynamy od braku głębi i na tym samym kończymy, wydaje się, jakby głębia była po prostu efektem wirtualnym wytworzonym przez powierzchnię iluzji.

Interesujące jest również to, że na ścieżce dźwiękowej najazdowi kamery towarzyszy elektroniczny odgłos, który słyszymy podczas dalszej jazdy Marka, jakby przemoc dostrzeżona wizualnie miała swoja kontynuację na ścieżce dźwiękowej i trwała dalej, nawet gdy muralu już nie widać. Na krótką chwilę hałas przycicha, przekształcając się w dźwięk silników, gdy Mark i Morty (współlokator Marka, który również znajduje się w samochodzie) mijają dwóch policjantów na motocyklach, ale zaraz znów powraca podczas słynnej sekwencji, w której Mark jedzie przez przemysłową część LA pełną ogromnych, kolorowych billboardów z nazwami przedsiębiorstw. Wszystko to jest filmowane teleobiektywem, by maksymalnie spłaszczyć obraz. W ten sposób „sielankowa” przemoc, która pojawiła się w scenie z muralem, a potem została podjęta przez hałaśliwą ścieżkę dźwiękową, zostaje wprowadzona w doświadczenie wzrokowe „realnego” (diegetycznego) LA. To właśnie ta przemoc „spłaszcza” obraz, to znaczy destabilizuje różnicę pomiędzy iluzją a rzeczywistością. W końcowej części tej sekwencji samochód Marka jedzie ulicą, wzdłuż której wciąż ciągną się billboardy i słupy wysokiego napięcia, a na ścieżce dźwiękowej wciąż słyszymy industrialne odgłosy i nagle - hokus-pokus! - słupy zamieniają się w palmy Beverly Hills, a hałas się urywa. Jesteśmy znowu w „,normalnie” wyglądającej rzeczywistości, wśród zwykłych odgłosów ulicy, jednak wiara w oczywistość normalnej rzeczywistości została podważona: czy Bulwar Zachodzącego Słońca to rzeczywistość czy sielankowa iluzja? Albo bardziej niepokojące pytanie: czy ta różnica ma jakieś znaczenie w LA? 
To zagadnienie powraca w wątku dotyczącym Sunnydunes i pracującego w firmie Allena, który chce budować i sprzedawać domy na pustyni. Mamy nawet możliwość obejrzenia telewizyjnej reklamy tego projektu, w której plastikowe figurki uśmiechają się plastikowo; kobiety smażą plastikowe jajka na plastikowym bekonie w swych plastikowych kuchniach dla plastikowego dziecka i plastikowego „,pana domu", a plastikowi mężczyźni ćwiczą grę w minigolfa na plastikowej trawie. Jednak ta na pozór absurdalna reklama kryje interesujące odniesienia. Na pierwszy rzut oka to, co się w niej sprzedaje, wydaje się czysto eskapistyczną fantazją: Po co brać udział w miejskim wyścigu szczurów, kiedy można się cieszyć życiem, jakie proponuje Sunnydunes? (...) Zatem przestań doprowadzać się do szaleństwa $w$ tym nieszczęsnym zatłoczonym mieście. Wyprowadź się dzisiaj i zacznij swe życie na nowo w naszym domu Sunnydunes na słońcu. Lecz pustynia musi oferować coś więcej niż spokój i słońce, które przecież nie jest taką atrakcją dla mieszkańców słonecznego LA. I oczywiście oferuje pełen relaks życia na wolnym powietrzu: twój własny prywatny basen, szmaragdowozielona trawe kortów tenisowych, górska wodę z dębowych wiader, niezanieczyszczone powietrze oraz inne udogodnienia, które można podsumować za pomocą innego wyrażenia, jakie daje się usłyszeć w reklamie: twój własny prywatny ogród. Jednak ogród ten nie jest zwykłym obiektem, który może być po prostu mniej lub bardziej atrakcyjny - zostaje mu nadane moralne, a w końcu też polityczne znaczenie: Stań się człowiekiem niezależnym. Wykuwaj swój własny los, jak pionierzy, którzy kształtowali Zachód. A zatem przedmiotem oferty jest tu nie tylko dom i ogród, lecz także - w karykaturalnej formie - (biała) amerykańskość jako taka, pod postacią jednej z najbardziej trwałych amerykańskich fantazji, istniejącej co najmniej od czasów Crèvecœura i Jeffersona. Jest to sielankowa wizja amerykańskiej farmy jako rekreacyjnego ogrodu, w którym europejscy imigranci mogą zrzucić swą starą skórę i narodzić się na nowo lub w bardziej Jeffersonowskiej wersji, mogą zostać wybawieni przez uprawę ziemi od moralnej i fizycznej degradacji spowodowanej niewolniczą pracą najemną w miastach ${ }^{4}$.

W pismach Jeffersona najsłynniejszy wyraz tej fantazji, w której moralna i polityczna cnota są ze sobą ściśle powiązane, znajdziemy w Uwagach o państwie Wirginia, gdzie czytamy: Ci, którzy pracuja na roli, sq wybranym ludem Bożym, jeśli miat on kiedykolwiek wybrany lud, którego piersi uczynił on swa szczególna składnica rzeczywistej i prawdziwej cnoty. (...) Zepsucie zasad moralnych pośród masy rolników jest zjawiskiem, którego przykładu nie dostarczyła żadna epoka ani żaden naród. Piętnem tym naznaczeni sa ci, którzy dla swego utrzymania nie poważaja nieba, swej ziemi oraz pracy tak jak gospodarz, lecz zależa od przypadków i kaprysów klientów. Uzależnienie rodzi stużalczość i sprzedajność, dusi w zarodku cnote i przygotowuje zdatne narzędzia nieuczciwych zamiarów. (...) To obyczaje i charakter ludu sa tym, co zachowuje żywotność republiki. Ich degeneracja jest niczym rak, który rychto wgryza się $w$ serce jej praw i konstytucji ${ }^{5}$.

Amerykańskie cnoty, takie jak indywidualizm, niezależność, pewność siebie i samostanowienie, wiąże Jefferson bezpośrednio z wyrzeczeniem się miejskiego życia i pogoni za zyskiem. Jego farmer jest zadowolony z tego, jak żyje, ponieważ nie czuje potrzeby akumulacji: Wirginijski farmer na swej rodzinnej farmie będzie produkowat wszystko, czego potrzebuje jego rodzina, a nawet trochę więcej. Celem jest samowystarczalność, nie wzrost ekonomiczny - prawie calkowity zastój, który 


\section{SŁAWOMIR MASŁOŃ}

towarzyszy pożąanym równowadze psychicznej i spokojowi. (Należy zauważyć, że „trwałość rzadów” jest jedna z głównych trosk Jeffersona.) Poprzez zrównanie pragnień z potrzebami oraz odwrócenie się od przemystu i handlu gospodarz będzie wolny od tyranii rynku. Nieistnienie skomplikowanych ekonomicznych zalezności uprawdopodabnia tutaj nieobecność tego, co im zwykle towarzyszy struktury klasowej. Jefferson opiera to szczęśliwe bezklasowe państwo na rzeczywistym posiadaniu ziemi przez farmera; $w$ takim społeczeństwie wszyscy ludzie przyjma wyniosta patrycjuszowska postawe wobec zachowań powodowanych $\dot{z} a \mathrm{~d}$ za zysku ${ }^{6}$.

Najważniejszymi terminami są tu „zastój”, „równowaga” i ,spokój”. Jefferson propaguje sielankowy ideał harmonijnego społeczeństwa, to znaczy społeczeństwa, w którym nie ma sprzeczności (sprzecznych interesów), a zatem nie ma w nim czynników, które mogłyby je zdestabilizować. Innymi słowy, zrównoważony i spokojny stan takiego społeczeństwa implikuje, że pozostaje ono w stanie zastoju jest to społeczeństwo egzystujące poza historią. Dlatego właśnie Jefferson nie cierpi miast: industrializacja (a z nią płacowe niewolnictwo) to sposób, w który historia w jego czasach zawłaszcza amerykańską ziemię.

W zasięgu wzroku Jeffersona, w Wirginii, istniały głównie majątki oparte na pracy niewolniczej, a dalej na północy, jak wiedział z doświadczenia, ponure industrializujące się miasta i ledwo wiążący koniec z końcem jankescy farmerzy. Ponieważ jednak żył on w czasach otwartej Granicy (między białą cywilizacją a „dziczą"), mógł sobie wyobrażać, że idealna sielankowa republika jest tworzona zaraz za horyzontem przez cnotliwych pionierów, którzy kształtują Zachód. Fantazja ta, uwspółcześniona i kanonizowana przez amerykański transcendentalizm, funkcjonowała nieprzerwanie przez cały wiek XIX (póki w 1890 r. nie ogłoszono zamknięcia Granicy), zawsze kosztem przeniesienia sielankowej sceny poza zasięg wzroku, czyli w królestwo fantazji znajdujące się poza horyzontem.

Co jednak dzieje się z fantazją, gdy horyzont (jak Granica) znika? Innymi słowy, gdzie dokładnie znajduje się przestrzeń, która jest reklamowana przez firmę Allena? By odpowiedzieć na to pytanie, wystarczy przyjrzeć się jej nazwie: Sunnydunes Development (development - rozwój/rozbudowa) - reklamuje ona rozbudowę LA przez wyznaczenie wyobrażeniowej granicy między Jeffersonowskim „nieszczęsnym miastem” i sielankowymi „domami Sunnydunes”. Ponieważ LA otocza pustynia, domy Sunnydunes będą budowane na obrzeżach istniejącej metropolii i chociaż kilka pierwszych, a nawet kilkadziesiąt pierwszych może na początku wyglądać na „niezależne” od miasta, firma planuje, jak słyszymy w gabinecie Allena, zainwestować w ten projekt 200 milionów dolarów od razu i miliardy w przyszłości. Zatem po niedługim czasie „niezależne” domy zaczną po prostu stanowić nowe dzielnice LA ciągnące się coraz dalej i dalej w głąb pustyni. Oznacza to, że od samego początku linia podziału między złym miastem i dobrym ogrodem-farmą (niegdyś horyzont) jest dla metropolii wewnętrzna i przyjmuje postać granicy wirtualnej, która oddziela miasto od niego samego. Innymi słowy, metropolia jest „nieszczęsnym miastem”, ale zarazem jest też „twoim własnym prywatnym ogrodem", to znaczy obraz miasta i obraz ogrodu zostają na siebie nałożone, choć nigdy nie będą sobie dokładnie odpowiadać. Efekt takiego nałożenia jest doskonale oddany przez Antonioniego we wspomnianej wcześniej sekwencji: Beverly Hills jest ,rzeczywiste”, a jednak wygląda jak swój własny mural ${ }^{7}$. 
Logikę tę można też zilustrować w inny sposób: właśnie wtedy, gdy nie ma już gdzie uciec, deweloper, by rozbudowywać (przyciągnąć klientów), musi odwołać się do fantazji ucieczki od rozbudowy, a zatem różnica między „tak” i „nie” - odróżniającą rozbudowę od nie-rozbudowy lub miasto od natury - staje się czysto strategiczna, wewnętrzna dla samej rozbudowy (miasta). Takie „uwewnętrznienie” horyzontu - linii granicznej między przestrzenią rzeczywistą a przestrzenią fantazji - w miejskiej przestrzeni jest operacją, która pozwala na nieograniczoną rozbudowę we wszystkich kierunkach, ponieważ w takiej przestrzeni ,zewnętrzny” horyzont nie istnieje ${ }^{8}$. W Zabriskie Point widzimy taką pozbawioną horyzontu przestrzeń, gdy Mark kradnie awionetkę i ogląda LA z lotu ptaka. Chociaż miasto jest filmowane z dużej wysokości, punkt zbiegu, w odniesieniu do którego Mark mógłby określić swe położenie, nie istnieje: budynki rozciągają się coraz dalej i dalej, stopniowo przekształcając się w zielonkawą mgłę, która z kolei nabiera niebieskawego zabarwienia, by w końcu zamienić się w niebo. Lee Allen panuje w tej wirtualnej przestrzeni, która jest bezkresna (zawsze można wyobrazić sobie o jeden dom więcej) i nie stawia żadnego oporu (rozbudowie) - gdy jeden z decydentów Sunnydunes proponuje zarezerwować 40 milionów na niespodziewane wydatki, Allen odpowiada: Po co odkładać 40 milionów dolarów na niespodziewane wydatki? To znaczy - na jakie niespodziewane wydatki? Jednak w tej bezkresnej wirtualnej przestrzeni nie można odetchnąć pełną piersią - wręcz przeciwnie: człowiek się w niej dusi ${ }^{9}$. Wytwarza ona płaską, klaustrofobiczną, halucynacyjną nierealność miejskiego doświadczenia, oddaną przez Antonioniego w sekwencji przejazdu Marka i Morty'ego przez LA.

W filmie Antonioniego istnieje także inny rodzaj przestrzeni - jest to pustynia, na której ścieżki Marka i Darii się przetną. Uciekając od tego, co stało się na kampusie, Mark wsiada do autobusu i jedzie nim do końcowego przystanku, którym okazuje się Hawthorne, gdzie kradnie różową Cessnę, by spojrzeć z lotu ptaka na LA, a potem na pustynię. Droga Darii jest bardziej kręta. Pożycza starego Buicka i wyrusza w podroż do Phoenix (a raczej do Carefree, pokazowego osiedla około trzydziestu mil na pótnoc od Phoenix ${ }^{10}$ ), gdzie w willi na skraju pustyni ma się spotkać z Lee Allenem, swym szefem. Nie jedzie tam wszakże bezpośrednio - najpierw zbacza z drogi, by odnaleźć miasteczko Ballister i spotkać się tam z przyjacielem, Jimmym Pattersonem, który powiedział jej, że jest to fantastyczne miejsce do medytacji. Zatem podążamy za dziewczyną noszącą modną zieloną tunikę (w kolorze sielskiej natury) i indiańskie ozdoby, która szuka dobrych warunków do medytacji, by zharmonizować swe życie ze swoim wewnętrznym (naturalnym) ja. Jednak to, co znajduje w Ballister, jest dalekie od harmonijnej natury skłaniającej do medytacji - jest to miasto-widmo, po którym walają się odpady cywilizacji przemysłowej. Mimo to Ballister ma co najmniej jedną cechę sielanki: zastój - klienci baru, który odwiedza Daria, to zniszczeni życiem staruszkowie patrzący stoicko w dal. Wszystko, co mogą robić w tym widmowym miasteczku, to właśnie „medytować”, a film doskonale to ukazuje w postaci mężczyzny w kowbojskim kapeluszu, który przez cały czas epizodu rozgrywającego się w Ballister po prostu siedzi przy barze nad szklanką z piwem, wpatruje się w ścianę (czyli w siebie) i pali papierosa, całkowicie obojętny na otaczającą go rzeczywistość - prawdziwy amerykański Budda.

Kim są ci zamyśleni staruszkowie i co robią w widmowym miasteczku? W fantasmagorycznym LA nie ma ,prawdziwych” pionierów, jedynie ich plastikowe 


\section{SŁAWOMIR MASŁOŃ}

(wirtualne) odpowiedniki, ponieważ jego gładka, niestawiająca oporu przestrzeń nie wymaga (nawet nie pozwala na zaistnienie) ludzi, których ukształtowały (lub mogłyby ukształtować) indywidualizm, niezależność i wytrzymałość. Jednak można ich znaleźć (choć w ledwie rozpoznawalnej formie) w Ballister, gdzie są reprezentowani na przykład przez bezzębnego Johnny’ego Wilsona, mistrza świata wagi średniej z 1920 roku, którego Daria spotyka w barze. Wbrew pozorom (mężczyźni siedzą, słuchając Tennessee Waltz, nostalgicznej piosenki o utraconej miłości śpiewanej przez Patti Page) miasteczko i jego wiekowi mieszkańcy nie stanowią nostalgicznego obrazka odchodzącego w przeszłość starego Zachodu, opartego na Jeffersonowskich cnotach i możliwego do zawłaszczenia przez fantazję ucieczki z tego nieszczęsnego, zatłoczonego miasta. W rzeczywistości opłakany stan Ballister ma czysto historyczne źródła. Główne znaczenie w rozbudowie LA jako miasta zielonej roślinności i turkusowych basenów miał transfer w jego rejon wielkich ilości wody z otaczających terenów, w efekcie czego farmy i gaje pomarańczowe, które istniały wokoło dzięki tej wodzie, umarły i zamieniły się w pustynię ${ }^{11}$. Dlatego też Ballister i jego nie tak znów sielankowy zastój są pozostałością po rzeczywistej historycznej przemocy, której użyto, by ahistoryczne sielankowe miasto mogło zaistnieć. Jednak ślady tej przemocy zostały całkowicie usunięte z wirtualnej rzeczywistości sielanki - trzeba udać się na pustynię w poszukiwaniu spokoju, by okazało się, że znaleziony tam spokój jest dziełem człowieka, a nie natury i że właściwie wcale spokojem nie jest. Dlatego nie jest zaskoczeniem, że epizod, który zaczyna się jako nudna wizyta w zakurzonym muzeum dawnego Zachodu, kończy się przemocą, paniką i szybką ucieczką. Kilkunastu chłopców, sprowadzonych do Ballister z LA przez Jimmy’ego Pattersona, otacza Darię i domaga się od niej trochę tytka (a piece of ass). Gdy Daria bierze to za żart, chłopcy łapią ją i próbują zedrzeć z niej majtki, aż w końcu udaje jej się wyrwać i uciec. W miejscu, które stanowi ślad wymazanej z pamięci historycznej przemocy, Daria napotyka przemoc, która wydaje się niewyttumaczalna - materializuje się ona bez powodu znikąd i znika w ten sam sposób (choć jest ona w jakiś mglisty sposób związana z LA).

Jednak nie wszystkie ślady historii udało się wymazać z wirtualnej przestrzeni sielanki - rozrasta się na niej czarna plama. Choć walka polityczna czarnych z sielankową fantazją, której bronią siły policyjne, jest bezpośrednio pokazana tylko na początku Zabriskie Point, stanowi ona główną oś filmu, ponieważ jest ściśle związana z postawą Marka. Gdy Mark i Morty jadą przez LA, wątek polityczny zostaje podjęty dokładnie w miejscu, w którym został przerwany, kiedy Mark wyszedł z zebrania przedstawionego na początku filmu. W odpowiedzi na drwiącą uwagę Marka: Dzień, w którym przestaniecie spodziewać się porażki, będzie dniem, gdy dołącze do waszego ruchu, Morty odpowiada: A co jeśli przyłaczenie się nie jest kwestia wyboru? Dla wielu ludzi to kwestia przetrwania. Kogo Morty ma tu na myśli? Siebie? Choć w filmie nie dowiadujemy się tego, prawdopodobnie, jak większość białych studentów, których widzimy w Zabriskie Point, Morty wywodzi się z klasy średniej, a Mark jest najprawdopodobniej „,czarną owcą” bogatej rodziny (na jednym ze skrzyżowań Bulwaru Zachodzącego Słońca Mark i Morty prawie zderzają się z luksusowym kabrioletem siostry Marka). A zatem możemy tu tylko powrócić do tego, co zostało powiedziane na zebraniu studentów: człowiek, który nie ma wyboru, to taki, który nie może znaleźć pracy, nie może pójść do szkoły, nie ma co jeść itd., czyli czarny Amerykanin. Właśnie to mam na myśli-odpowiada 
Mark na uwagę Morty'ego: To nie jest zabawa. I wątek polityczny filmu rozwija się właśnie w tym kierunku. Chociaż kilkudziesięciu studentów i ich profesorów zostaje aresztowanych i poturbowanych przez policję za protesty na kampusie, wypuszcza się ich na wolność po spisaniu ich danych, podczas gdy czarni studenci, którzy zabarykadowali się w bibliotece, zostają spacyfikowani gazem łzawiącym i traktuje się ich jak niebezpiecznych kryminalistów (policjanci otaczający bibliotekę nie mają pałek, lecz broń palną) a jeden z czarnych studentów zostaje zastrzelony. Obecny przy tym Mark - wierny swemu słowu, że dla niego, tak jak dla czarnych, to nie zabawa - wyciąga z cholewki buta pistolet, by zabić policyjnego strzelca, jednak ktoś uśmierca go wcześniej.

Dlaczego Mark jest gotów zabić policjanta? Gdy Mark z kolegą kupują broń, przekonują sprzedawcę, by nie sprawdzał ich w kartotece policyjnej, mówiąc, że mieszkają w okolicy, która jest, no wie pan, graniczna (mając na myśli, że graniczy ona z czarnym gettem) i dlatego muszą chronić swe kobiety. Jednak wydaje się, że miejsce, w którym mieszkają Mark i Morty, nie znajduje się nawet w strefie ,granicznej”, ponieważ za każdym razem w ich otoczeniu widzimy wyłącznie Afroamerykanów. Co więcej, w dalszej części filmu, podczas jednej z rozmów na pustyni między Markiem a Darią, gdy słyszymy jak dziewczyna żartobliwie prosi go, by zapoznał ją z resztą swej kartoteki policyjnej (właśnie opowiedział jej, dlaczego został wyrzucony z uczelni), Mark mówi: Raz zmieniłem kolor, ale niezbyt się to udało, więc wróciłem do poprzedniego. Daria uznaje to za dowcip, którym oczywiście także jest, jednak ma on również poważny podtekst, którego Daria nie może zrozumieć, ponieważ prawie nic o Marku nie wie. Identyfikując się z walką czarnych, Mark wierzy, że czyn z użyciem przemocy, jak zabicie białego policjanta w odwecie za zabicie czarnego studenta, symbolicznie uczyniłby go czarnym w sposób nieodwracalny (to znaczy zostałby przez policję potraktowany jak czarny), jednak ponieważ nie udało mu się tego zrobić, stał się ponownie biały. Identyfikacja Marka zostaje również podkreślona przez historyczną paralelę, do której odwołuje się on w swym ironicznym komentarzu do uwagi Darii, która mówi mu, że słyszała w radiu, iż facet, który zabit glinę [na kampusie], byt biały. Rany, biały chwytajacy za broń w imieniu czarnych, co? Jak stary John Brown.

Pora jednak powrócić na pustynię. Daria jedzie dalej w kierunku Doliny Śmierci, to znaczy wjeżdża na ,prawdziwą” pustynię, niebędącą efektem działalności człowieka jak Ballister. Ale zanim ruszymy za nią na spotkanie z Markiem, dzieje się coś dziwnego. W ujęciu, w którym widzimy jej samochód odjeżdżający spod baru, kamera nie podąża za samochodem, lecz rozpoczyna powolny najazd na jedno z jego okien. Widzimy przez nie amerykańskiego Buddę z papierosem i szklanką piwa, który wciąż siedzi w tym samym miejscu i wpatruje się w przestrzeń do melodii Tennessee Waltz. Kamera zbliża się coraz bardziej do okna, a następnie przenika przez nie jak duch, co jest standardowym filmowym trikiem, który umożliwia obiektyw zmiennoogniskowy. Jednak po chwili kamera cofa się do miejsca, gdzie kilka sekund temu znajdowała się szyba, ale już jej tam nie $\mathrm{ma}$ - granica, która oddzielała to, co na zewnątrz (ulica/pustynia), od tego, co wewnątrz (sala barowa), zniknęła. W pierwszej chwili trik ten wygląda na formalną „ilustrację” wewnętrznej przestrzeni, w której pogrążony jest Budda, obojętny na otaczający go świat (w opisywanym ujęciu w barze nie ma nikogo innego); jednak, biorąc pod uwagę szerszy kontekst filmu, dzieje się tu także coś innego. 
Po cięciu znajdujemy się po raz pierwszy na prawdziwej pustyni. Jednak nie jest to po prostu kolejna geograficzna lokalizacja, jak myślą o niej deweloperzy (ich wirtualna przestrzeń jest nieskończona i homogeniczna). Wyparta historyczność zmaterializowana jako widmowe miasteczko stanowi ,linię uskoku”, minąwszy którą, wkraczamy w inny wymiar przestrzeni. Jest to formalnie zasugerowane w wyżej wspomnianym ujęciu z Buddą - technicznie składa się ono z połączenia dwóch momentów z wcześniejszej partii filmu. Jednym $\mathrm{z}$ nich jest wspomniany już gwałtowny najazd kamery na biedaka kradnącego świnię na sielankowym muralu znajdującym się na budynku zakładów mięsnych. Innym tego rodzaju sielankowym obrazem w filmie jest reklama Sunnydunes. Zawiera ona fragment, który odpowiada kradzieży świni w harmonijnej, „,naturalnej” scenerii: w słonecznej, plastikowej Arkadii, w której każdy jest wysportowany, uśmiechnięty, zadowolony i biały, małe dziecko siedzące w wózku obok swej plastikowej mamusi, w jej w petni urządzonej kuchni Sunnydunes, bezgłośnie drze się wniebogłosy, jakby je obdzierali ze skóry. Film podkreśla to w dokładnie odwrotny sposób niż w przypadku muralu: zaczynając od zbliżenia twarzy dziecka, kamera błyskawicznie odjeżdża, by włączyć w kadr stół pełen plastikowych wiktuałów. A zatem mamy tu do czynienia z dwoma „plamami”, które rozsadzają (lub przynajmniej zakłócają) dwa zaoferowane nam obrazy płaskiej sielankowej harmonii, a tym samym sugerują inny wymiar niż przestrzeń rozbudowy. Ujęcie z Buddą wiąże ze sobą obie plamy przez nałożenie dwóch wspomnianych ruchów kamery: według Boba Rubina, asystenta Antonioniego w trakcie pracy nad filmem, zostało ono nakręcone z wykorzystaniem kombinacji najazdu za pomoca zoomu i odjazdu do tyłu wózkiem ${ }^{12}$.

Przekroczywszy linię uskoku, znajdujemy się w innej przestrzeni. Ale co sprawia, że jest ona inna? Pierwszą sugestię można dostrzec zaraz po cięciu: jest to idealnie prosta linia kolejowa, za którą awionetka Marka podąża w głąb pustyni. Pustynia, którą spotykamy w tej części filmu, znacznie rożni się od tego, co widzieliśmy w Ballister. To głównie Dolina Śmierci, która - jak dowiadujemy się $\mathrm{z}$ pokazanej w filmie tablicy umieszczonej w tytułowym Zabriskie Point (jest to punkt widokowy na pustyni) - jest obszarem prehistorycznych niecek jezior utworzonych pięć do dziesięciu milionów lat temu. Niecki te zostaty przechylone $i$ wypchnięte do góry przez siły ziemskie, a następnie uległy erozji przez wiatr $i$ wodę. Innymi słowy, choć Dolina Śmierci jest tworem naturalnym, jest ona ruiną natury, rozumianej nie tylko sielankowo, jako rolniczy krajobraz w klimacie umiarkowanym, ale nawet w sensie ,pierwotnym” (dziewicze lasy nietknięte przez człowieka itp.). Właśnie dlatego, że jest ruiną, pustynia stawia opór (ze wzgledu na swój wiek, rozległość, pustkę itd.) wyobrażeniom, które ludzki umysł chciałaby jej narzucić i w ten sposób konfrontuje człowieka z ni e po znawalny m (przeciwieństwem niestawiającej oporu przestrzeni rozbudowy). Otrzeźwiająca siła takiej konfrontacji to locus classicus amerykańskiego dyskursu propagującego potrzebę zachowania w nienaruszonym stanie pozostałej na kontynencie dzikiej przyrody, który - co nie dziwi - zaczął zyskiwać popularność z chwilą ogłoszenia zamknięcia Granicy ${ }^{13}$. Metafora, której przez ostatnie ponad sto lat najczęściej używano w tym kontekście, mówi, że w otoczeniu dzikiej przyrody ludzki umysł, ściśnięty w zatłoczonym mieście, ro zs zerza si ę. We wczesnych latach ruchu ochrony przyrody rozszerzeniu temu często nadawano znaczenie religijne, które dziś zyskuje zsekularyzowaną kontynuację w naturalistycznej poetyce autentyczności (znajdowanie prawdziwej 
tożsamości w kontakcie z dzika przyrodą). Jednak mistyczne podpórki nie są konieczne, by opisać mechanizm tego rozszerzenia. Istnieje nawet klasyczna książka poświęcona ochronie pustyni - pierwszy raz opublikowana w 1967 r., a zatem mniej więcej współczesna Zabriskie Point - która analizuje ten mechanizm całkiem dobrze. Choć Desert Solitaire Edwarda Abbey popada czasem we wspomnianą wcześniej poetykę autentyczności: Czyste powietrze do oddychania (...), cisza, samotność, przestrzeń; niczym nie przysłonięty widok każdego dnia i nocy na słońce, niebo, gwiazdy, chmury, góry, księżyc, skaty i kaniony; poczucie wystarczającej ilości czasu, by myśl i uczucie mogły rozciagnać się (range) stąd do końca świata i z powrotem; odkrycie czegoś bliskiego (intimate) - choć niemożliwego do nazwania - w tym, co odlegle ${ }^{14}$.

Tym, co umożliwia umysłowi ekstatyczne rozszerzenie się na pustyni, jest obecność horyzontu (końca świata), który pozwala na odświeżenie myśli i uczuć. Skąd jednak bierze się uczucie obecności czegoś bliskiego $w$ tym, co odległe, to znaczy w samym horyzoncie właśnie? Tym „czymś” bliskim jest oczywiście tak zwany punkt zbiegu - wirtualny (obiektywnie nieistniejący) punkt, w kierunku którego z mojej perspektywy biegną wszystkie linie i w którym się spotykają. Jest to punkt, w którym ja jako podmiot patrzący (jako zasada organizująca moje widzenie) jestem obecny w krajobrazie (w tym, co widzę) jako wielkość nie wi a d o ma (niemożliwa do nazwania) i jako coś, co rozszczepiając mnie pomiędzy moim miejscem obserwacji i horyzontem, czyni ze mnie podmiot pragnący, to znaczy pozwala mi oddychać całą przestrzenią rozciągającą się do końca świata i z powrotem. Abbey po raz kolejny trafia w sedno, gdy określa ten podmiot (samego siebie) jako człowieka o niewielkich potrzebach, nieskończonych pragnieniach ${ }^{15}$ : tylko w przestrzeni ograniczonej przez horyzont pragnienia i widzenie mogą rozciągać się nieskrępowanie, podczas gdy uwewnętrznienie horyzontu skutkuje odrealnieniem świata i klaustrofobią. Dlatego właśnie w całej sekwencji filmu rozgrywającej się na pustyni drogi komunikacyjne (linia kolejowa, szosa) są prawie całkowicie proste, horyzont jest wyraźnie widoczny, a panoramiczne widoki mają punkt zbiegu. Prawdziwe piękno pustyni polega na jej obojętności: pozostaje ona tylko sobą, opierając się ludzkim próbom symbolicznego jej zawłaszczenia. Jednak taka bezużyteczność może być w rzeczywistości bardzo użyteczna - może umożliwić człowiekowi oczyszczenie swych potrzeb, by pozostała tylko naga jaźń (the naked self) ${ }^{16}$ : czyste (nieskończone) pragnienie. Pustynia daje szansę odjazdu na punkcie rzeczywistości (reality trip), którego można doświadczyć, jeśli pozwoli się jej działać i pozostawi za sobą sielankowe uprzedzenia.

Dla obojga bohaterów, Marka i Darii, pustynia stanowi „objazd” - znajdują się na niej, zboczywszy z zamierzonego kursu. Daria, jak już wspomnieliśmy, robi to w poszukiwaniu „natury”; Mark, ponieważ potrzebował wznieść się ponad ziemię (I needed to get off the ground), to znaczy uciec od miasta i od policji, by podjąć decyzję, co robić dalej, ale także by „odlecieć”, doświadczyć uderzenia adrenaliny, by przezwyciężyć stan zamętu panujący w jego głowie (wcześniej widzieliśmy, jak Mark robi coś podobnego: przejeżdża przez skrzyżowanie na czerwonym świetle). Daria ma określony plan podroży (LA - Ballister - Phoenix), podczas gdy Mark właściwie nie wie, co począć. Wydaje się, że porzuciwszy swe dawne życie (chłopaka z Beverly Hills), nie ma określonej tożsamości i usiłują wykuć swoją własną (co znaczy być rzeczywiście wolnym Afroamerykaninem), podczas 
gdy Daria jest pewnym siebie, odzianym w zieleń i noszącym indiańskie ozdoby „dzieckiem ziemi”, które pragnie „być sobą” (statyczny ideał arkadyjski). Dlatego nic dziwnego, że natychmiast czyni z pustyni dom: Nie czujesz się tu jak w domu? - pyta Marka - Pustynia jest taka spokojna. - Jest martwa - odpowiada on bez entuzjazmu. Przeciwko temu stwierdzeniu Daria wymyśla „grę śmierci” - ma ona udowodnić, że pustynia nie jest martwa, że jest częścią natury, pełną roślin i zwierząt. Jest to oczywiście prawda (każda pustynia to ekosystem), ale Markowi chodzi o coś zupełnie innego - sprzeciwia się „udomawianiu”: nie z każdej przestrzeni można, a nawet powinno się robić dom (nie wszystko może, a nawet powinno służyć samorealizacji). Podczas gdy Daria przedstawia udomowienie jako uniwersalne rozwiązanie problemów świata (Istnieje tysiac racji, nie tylko bohaterowie i łotry), Mark odrzuca je jako coś, co przyczynia się do tworzenia tych problemów (Jeśli nie widzi się w nich łotrów, nie można się ich pozbyć). Innymi słowy, gdy Daria dokonuje udomowienia za pomocą mnożenia perspektyw (tysiąc racji), Mark opiera się temu, ustanawiając horyzont znaczenia ( $W$ końcu człowiek musi opowiedzieć się po jednej ze stron). Co więcej, szybko wychodzi na jaw, co leży u źródła impulsu udomawiania przez naturalizację: Byłoby fajnie, gdyby można było sadzić myśli w naszych głowach, tak by nikt nie miat złych wspomnień (...); tylko dobre rzeczy. Trudno byłoby znaleźć lepszą metaforę na życzeniowe sielankowe fantazjowanie, którego Daria jest doskonałą praktykantką - dobre myśli mogłyby przysłonić blizny osobistej historii (Tak, by człowiek mógł zapomnieć, jakie okropne to było w rzeczywistości - mówi Mark). Jednak na płaszczyźnie społecznej i politycznej taka transplantacja już się dokonała: dla złych wspomnień o Ballister zmienionym w pustynię nie ma miejsca w sielankowej fantasmagorii LA, dla której dezertyfikacja nigdy się nie zdarzyła. W takim świecie nic nie jest straszne, jak twierdzi Daria, a obstawanie przy tym, że istnieją sprzeczności, uważa się wyłącznie za przejaw niedostatku wyobraźni ${ }^{17}$.

Myślenie Darii zostaje w końcu uzewnętrznione w filmie w jej fantazji, w której akt seksualny z Markiem zostaje powielony przez wielu innych młodych ludzi (Istnieje tysiac racji). Tarzają się oni w piasku, przybierając barwy ziemi - w ten sposób jednoczą się z nią i uosabiają samą zasadę życia. W tej scenie wszystkie podziały zostają przezwyciężone i niezróżnicowana ziemia kocha się sama ze sobą; osoby tworzące pary różnią się od siebie tylko „strategicznie” - pokryci piaskiem partnerzy wyglądają prawie identycznie. W ten sposób znajdujemy się ponownie w gładkiej, niestawiającej oporu przestrzeni nieograniczonej przez horyzont. Jednak tym razem śmiercionośna podbudowa tej fantazji staje się znacznie bardziej widoczna: jedynym sposobem, by stać się jednością z pustynią, jest obrócić się w proch (by przeżyć w tych warunkach, trzeba się chronić za pomocą wynalazków cywilizacji, takich jak samochód albo samolot).

W scenie uniwersalnej miłości wyobrażonej przez Darię stopienie się z ziemią sugeruje również afirmującą życie, „,naturalną”, to znaczy niewinną seksualność; jednak reżyser wcześniej pokazał, że seksualność w szczególny sposób opiera się sielankowej wizji. W fantazji Darii seksualność pojawia się w filmie w sposób bezpośredni po raz czwarty. „Nalot” awionetki Marka na samochód Darii można uznać za zabawę, jednak zawiera ona element agresji: Mark jest panem sytuacji i bezwzględnie wykorzystuje swoja przewagę. Inny typ relacji seksualnej przedstawiony w filmie jest jeszcze bardziej złowieszczy: jeśli szef proponuje sekretarce wy- 
cieczkę do kurortu na pustyni, wiadomo, czego od niej oczekuje. A jeśli chcemy wskazać w Zabriskie Point wiarygodny obraz niewinnej („naturalnej”) seksualności, nie należy go szukać w sielankowej fantazji Darii, ale w miejscu, w którym sielanka ukazuje swoje nieprzyjemne oblicze: w Ballister, gdzie dzieci „spontanicznie" rzucają się na bohaterkę, by zedrzeć jej majtki.

Jednak pomimo początkowej potrzeby dominacji (w końcu można ją przypisać „godowym” rytuałom tamtych i nie tylko tamtych czasów), Mark stopniowo poddaje się urokowi „hipisowskiej” fantazji Darii i ich akt seksualny jest tu momentem zwrotnym. Jego zmieniająca się postawa znajduje bezpośredni wyraz w dialogu, który słyszymy po scenie uniwersalnej miłości:

Mark: Zawsze wiedziałem, że tak to będzie wyglądało.

Daria: My?

Mark: Pustynia.

A zatem, zapominając o tym, co wypowiedział wcześniej (Jest martwa), Mark zaczyna brać udział w udomawianiu pustyni. I celem sceny, która następuje bezpośrednio po jego akcesie do sielanki, jest prześmiewcze pokazanie nieprzystawalności domu i pustyni: przy Zabriskie Point parkuje kamper, z którego wysiada otyła para z dzieckiem, a absurdalność ich obecności na pustyni jest dodatkowo podkreślona tym, że kamper ciągnie za sobą przyczepę z łodzią motorową, a dziecko liże lody. Rodzina jest też przedstawiona jako bezpośrednie przedłużenie impulsu rozbudowy: mężczyzna mówi o budowie restauracji dla zmotoryzowanych w tym punkcie widokowym, na czym można by zarobić mnóstwo pieniędzy, a ich obecność w Zabriskie Point jest podsumowana na ścieżce dźwiękowej odgłosem silników odrzutowca, który wcześniej towarzyszył biznesmenom wysiadającym z samolotu w Hawthorne. Co więcej, za turystami i ich ruchomym domem podąża ich nieodłączne towarzystwo: radiowóz policyjny (bezsensowna rozbudowa równa się bezsensowna przemoc), który zatrzymuje się na parkingu zaraz po odjeździe turystów. W ten sposób Mark, który powoli pogrąża się w błogostanie sielankowo-domowej fantazji, znajduje się w dziwnej sytuacji: $\mathrm{z}$ jednej strony zostaje mu przypomniana jego polityczna identyfikacja; $\mathrm{z}$ drugiej jednak wydaje się, jakby w przestrzeni antypolitycznej sielanki, w którą właśnie wkroczył, uczestnicząc w tworzeniu domu przez Darię, jego dawne pragnienia mogły być natychmiast zrealizowane i to, czego nie zdołał dokonać na kampusie, mogło się wydarzyć na pustyni. Ale oczywiście nie może się tak stać - sielanka jest bezpłodną fantazją, więc Daria musi stanąć pomiędzy Markiem a policjantem, by powstrzymać pierwszego przed zastrzeleniem drugiego. Choć fantazja kusi, materializując nasze pragnienia, w rzeczywistości jest ona niemożliwą do pokonania przeszkodą w ich realizacji - kupienie domu Sunnydunes na pustyni ostatecznie uniemożliwia stanie się niezależnym człowiekiem i kowalem własnego losu.

W filmie Mark został przedstawiony jako rozszczepiony, jako nieszczęśliwa świadomość podzielona między siebie a pewną nie-możliwość (zmianę koloru), która zmusza go do działania. Teraz to rozszczepienie zostaje skonfrontowane z możliwością jego zaleczenia dzięki fantazji sielankowej harmonii z ziemią (jako domem), która jak zwykle w ostatecznym rozrachunku sprowadza się do fantazji udanej relacji seksualnej (scena miłosna). Na jakiś czas Mark zostaje „naturalnie” obezwładniony przez Darię i jej piękne ciało, w którym jakby się materializowała sielankowa fantazja pokoju i spełnienia - do tego stopnia, że pozbywa się broni 


\section{SŁAWOMIR MASŁOŃ}

i zabiera się do upamiętnienia tej materializacji w symbolicznym przemalowaniu z Darią awionetki. Jednak charakterystyczne jest, że to, co ma być przesłaniem z pustyni, nie ma z nią nic wspólnego: awionetka, pomalowana głównie na kolor zielony (kolor sielanki, a nie pustynnej natury), staje się androgynicznym stworem z kobiecymi piersiami namalowanymi na skrzydłach i kadłubem przemalowanym na penisa, pokrytym napisami: Żadnych słów (pełni rozkoszy zmaterializowanej w androgynicznym stworze nie da się wyrazić słowami) oraz zaimkami on-ona-ono, jakby połączonymi w jedną całość. Ostatecznie okazuje się, że to przesłanie Darii, nie Marka: odmawia on pójścia za fantazją spełnienia w udanym związku i samorealizacji (Możesz porzucić [samolot] tutaj i jechać ze mna do Phoenixmówi Daria). Wbrew swym interesom Mark wybiera nieznane (swoje własne rozszczepienie) i leci z powrotem do Hawthorne, gdzie czeka na niego policja i śmierć. Jest to moment, w którym Mark (symbolicznie) zmienia kolor, ponieważ nie jest już traktowany jak biały mieszkaniec sielanki, a zatem w domniemaniu niewinny, lecz jako czarna plama na tej fantazji i dlatego w domniemaniu winny.

Daria rusza dalej do Carefree, jednak w przeciwieństwie do Marka zupełnie nieporuszona zarówno ich spotkaniem, jak i pustynią. Dalej jest kimś, kto nie ma odjazdu na punkcie rzeczywistości, kto łatwo wyobraża sobie rzeczy: gdy zmienia kanał w samochodowym radioodbiorniku na jakiś nadający muzykę country and western, nagle na poboczu pojawia się stado kłusujących koni. Po drodze Daria dowiaduje się z radia o śmierci Marka, co sprawia, że się zatrzymuje i zastanawia, czy nie wrócić do LA. Jednak ważniejsze jest to, jak zostaje przedstawiony sposób, w jaki go opłakuje - właściwie akt ten jest podzielony na trzy części. Gdy słyszy wiadomość, zjeżdża z szosy, zatrzymuje się, wysiada z samochodu i pośród pustynnych krzewów i kaktusów łagodnie kołysze się z nimi na wietrze (nie płacze) - to nie Daria opłakuje Marka, lecz wiatr. W końcu postanawia ruszyć dalej i po jakimś czasie dociera do domu na pustyni, gdzie Allen prowadzi rozmowy biznesowe. Niezauważona, mija kilka sztucznie wyglądających (,plastikowych”) kobiet wypoczywających na brzegu sztucznie wyglądającego („plastikowego”) basenu i wkracza do groty-komnaty, gdzie górska woda spływa po skalnej ścianie (dom jest rodzajem nowoczesnej willi zbudowanej na skale $\mathrm{z}$ widokiem na pustynię). Następnie wchodzi do naturalnie wyglądającej wody, która tworzy sadzawkę u podnóża ściany, pozwala, by woda spływała jej po twarzy oraz sukience i zaczyna płakać: to nie Daria płacze, lecz sama woda opłakuje Marka. W następnym ujęciu wszystkie podstawowe elementy natury (oprócz jednego) zostają zgromadzone razem: w planie ogólnym (z punktu widzenia Darii) widzimy ogromną szybę, za którą Allen i jego goście (bezgłośnie) dyskutują o interesach, podczas gdy pustynne skały, które otaczają dom, odbijają się w niej; obrazowi temu towarzyszy odgłos wody spływającej po skale i dźwięczących dzwonków wiszących za oknem, poruszanych przez wiatr. W ten sposób na płaskim wirtualnym ekranie, który sam w sobie jest niczym (przezroczystym szkłem), biznesowe układy i sielankowa fantazja pustyni jako domu, reprezentowana przez Darię, łączą się bez wysiłku i bezkonfliktowo, choć efekt tego nałożenia jest dość oniryczny (przestrzeń LA również została przedstawiona w filmie jako płaska i fantasmagoryczna).

Jednego żywiołu brakuje w tym obrazie natury - ognia. Jednak w następnym ujęciu, gdy widzimy w zbliżeniu twarze biznesmenów, między nimi pojawia się nowy element: indiańska służąca w średnim wieku, która podaje mężczyznom 


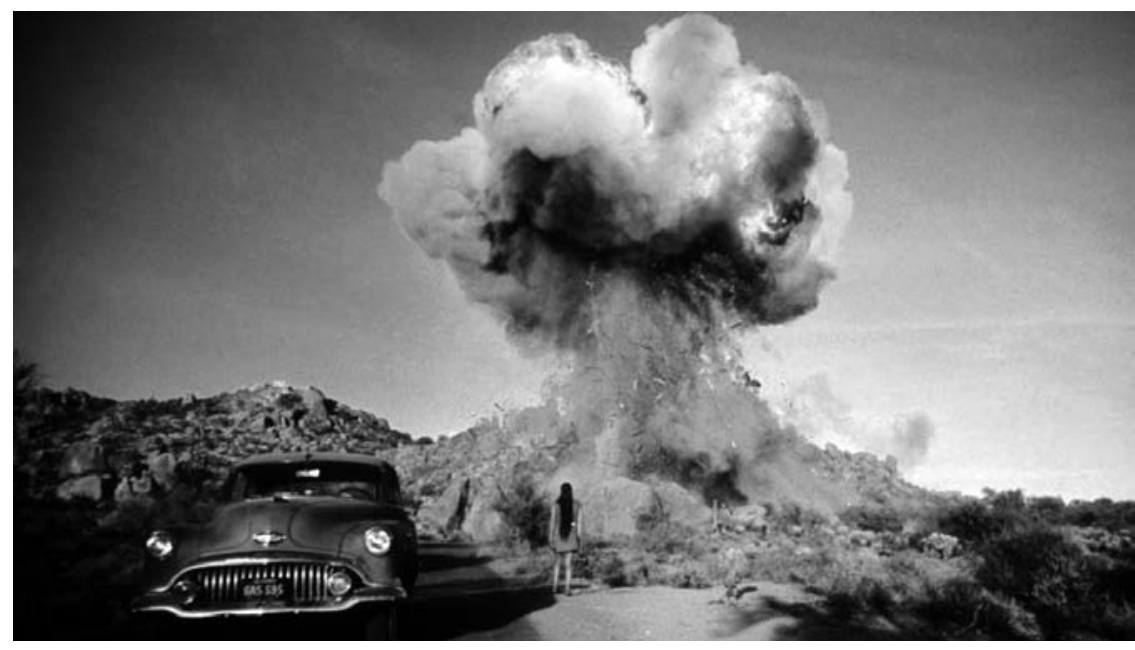

drinki. Gdy odkłada tacę i zaczyna wychodzić z kadru, zmienia się ostrość a odbicie Darii w szybie zostaje nałożone na postać służącej. Ponieważ, jak już zauważyliśmy, obraz Darii jako „dziecka ziemi” jest przez cały film podkreślany jej zieloną tuniką $\mathrm{i}$ indiańskiemi ornamentami, nietrudno zgadnąć, co się tu ukazuje: Daria patrzy na ekran sielankowej fantazji (obrazy natury paradoksalnie zawierają również biznesmenów), w której sama jest obecna (żyje tą fantazją) jako figura przesłaniająca nadmiarowy element niepasujący do reszty obrazu. Należy też dodać, że nie wydaje się, żeby nadmiarowy element (potencjalnie wybuchowy i dlatego funkcjonuje w zastępstwie brakującego ognia) na pierwszy rzut oka nie pasował Darii do reszty - bo właściwie dlaczego służąca serwująca drinki na spotkaniu biznesowym miałaby być elementem nie na miejscu? Jest ona kobietą w średnim wieku, a zatem wydaje się, że nie ma wiele wspólnego z młodą, piękną i niezależną Darią. Tylko kamera, przez nałożenie obrazów, widzi tu korespondencję. Jednak Daria po spotkaniu z Allenem, który kieruje ją do zarezerwowanego dla niej pokoju, na klatce schodowej staje twarzą w twarz z inną Indianką, pokojówką mniej więcej w jej wieku, wskutek czego biegnie przerażona do swego samochodu i natychmiast wyjeżdża.

Co wywołuje tak silną reakcję emocjonalną? Jako że sielankowa fantazja jest sposobem życia Darii, w fantazji tej ona sama jest czymś w rodzaju rdzennej Amerykanki (dzieckiem amerykańskiej ziemi - nawet pustynię wyobraża sobie jako dom). Jednak w Carefree spotyka prawdziwe dzieci pustyni i prawdziwe miejsce wyznaczone im w ahistorycznej sielance. Zostają w nią bez problemu wcieleni jako słudzy biznesmenów produkujących wirtualną przestrzeń, w której żyje Daria. Są służbą w dosłownym sensie, jako służące i pokojówki, ale również w sensie wirtualnym, jako „etniczna” rozrywka między innymi wytwarzająca „rdzennie amerykańskie" przedmioty, które nosi na sobie Daria. Ta niewidzialna inkorporacja skrywa jednak coś znacznie bardziej złowrogiego: tak jak Ballister jest śladem historii wymazanym $\mathrm{z}$ wirtualnej przestrzeni LA, tak rdzenni Amerykanie są pozostałością wymazanego z pamięci ludobójstwa, które zostało popełnione, by wirtualna przestrzeń ahistorycznej, białej, sielankowej fantazji ogrodu mogła zapanować niepodzielnie na amerykańskiej ziemi. Innymi słowy, by fantazja ta, fantazja wolności i samospełnienia mogła zostać zrealizowana, nie tylko ktoś musiał popaść w niewolę; byli też tacy, 
którzy musieli zniknąć z powierzchni tej ziemi. Dlatego lekcja Marka o tym, że nie istnieje tysiąc racji (różnych subiektywnych opinii o jednym, obiektywnym, niepodzielnym świecie, którego dzieckiem jest każdy), lecz w zasadzie tylko dwie (konflikt, który fantazja maskuje, tworząc obraz jednego i niepodzielnego świata), choć z opóźnieniem, zaczyna do Darii docierać. Odjeżdża ona na pewną odległość, zatrzymuje się, wysiada z samochodu i wpatrując się w dom, wysadza go w powietrze w swej wyobraźni (wciąż potrafi wyobrażać sobie rzeczy). Choć wizualnie jest to sekwencja filmu, która robi największe wrażenie, była to również ta jego część, która spotkała się z najbardziej zjadliwymi komentarzami krytyków: uważali oni, że fałszywy, ,plastikowy” obraz amerykańskiego materializmu (dom pełen artykułów konsumpcyjnych) został tu wysadzony w powietrze przez nierozumiejącego nic Antonioniego. Jednak jeśli wziąć pod uwagę kontekst, który został tu zarysowany, sekwencja ta ma chyba bardziej skomplikowane znaczenie.

Choć Daria może być nieprzyjemnie zaskoczona, gdy zda sobie sprawę, że sielankowa fantazja spokojnej i zaspokajającej natury, w której żyje, jest oparta na czystej przemocy (ludobójstwie), to jej ,naturalna” reakcja na tę wiedzę zachowuje c i ą g ło ść z tą fantazją dzięki wprowadzeniu ostatniego i brakującego elementu ognia - w jej relację z Markiem. Daria zjednoczyła się z ziemią w akcie miłosnym, potem $\mathrm{z}$ wiatrem, a następnie $\mathrm{z}$ wodą, opłakując Marka; teraz jednoczy się z ogniem (również jest on elementem Marka, jeśli wziąć pod uwagę jego związek z przemocą i bronią palną) w wyimaginowanej zemście. Można jednak zapytać: czy jest to rzeczywiście zemsta? Jak na akt zemsty, jest on raczej dziwnie mało gwałtowny ${ }^{18}$ zanim dom eksploduje, zostają pokazane jego wnętrza, które są pozbawione ludzkiej obecności, i choć wybucha on trzynaście razy (nie wliczając w to fragmentu w zwolnionym tempie), jak noworoczne fajerwerki, można podejrzewać, że powtórki służą wyłącznie intensyfikacji efektu czegoś, co inaczej można by wziąć za mało skuteczny gest. Co więcej, sekwencja następująca po wybuchu domu, w której eksplodują artykuły konsumpcyjne, jest nakręcona w przyspieszonym klatkażu i w oszałamiających kolorach, tak że przemoc, którą przedstawiają obrazy, zostaje całkowicie zneutralizowana. Dodatkowo eksplodujące fragmenty są filmowane na tle błękitnego nieba wyglądającego jak hiperrzeczywista woda basenu w LA i w połączeniu ze zwolnionym tempem tworzącego wirtualne środowisko, w którym pozbawione życia przedmioty (artykuły konsumpcyjne lub ich trudne do rozpoznania fragmenty) jakby się zmieniają w dziwne, kolorowe stwory wodne poruszające się na ekranie o własnych siłach. Daje to efekt nieważkości i wdzięku. Innymi słowy, element ognia, który miał zniszczyć sielankową fantazję, w rzeczywistości raczej ją wzmacnia, tak że wznosi się ona na nowe wyżyny - artykuły konsumpcyjne zyskują na ekranie własne fascynujące życie. Stają się wyższym wcieleniem wirtualnej natury, która ożywa na naszych oczach, czerpiąc siły - by tak powiedzieć - z pierwotnego impulsu destrukcji. Ta nowa ,natura” jest czystym chaosem, więc zapowiada koniec wszelkiego znaczenia; każdy z fragmentów jest oddzielony od wszystkich innych (a także od każdej możliwej użyteczności) i w ten sposób stanowi potencjalny ośrodek fascynacji jako przedmiot całkowicie zdekontekstualizowany. Widzieliśmy już, że w przestrzeni rozbudowy LA produkcja obrazów stała się ważniejsza niż produkcja dóbr, jednak wartość obrazów była determinowana ich symbolicznym kontekstem (sielankowa fantazja) i w ten sposób została im nadana pewna waga, podczas gdy w nowym nie-porządku, będącym skutkiem eksplozji, właśnie ich nieważkość, ich 
brak połączenia z czymkolwiek jest tym, co się liczy, ponieważ tylko nieważki przedmiot (obraz pozbawiony znaczenia) może fascynować ${ }^{19}$.

Dlatego nie wydaje się przypadkiem, że willa, która wybucha, jest modernistycznym budynkiem w stylu funkcjonalistycznym, w którym wszelkie ozdoby są zakazane. Eksplozja domu ustanawia przestrzeń, która jest dokładnym przeciwieństwem projektu funkcjonalistycznego: tworzy fragmenty, które są c zy s ty m i ozdobami samych siebie, nie tylko pozbawionymi domu, ale dzięki sile wywoływanej przez nie fascynacji wykluczającymi choćby cień możliwości istnienia nawet wirtualnego domu, na przykład domu stworzonego przez wspólną wiarę białych w sielankową Amerykę. Dlatego też ostatnia scena, w której Daria odjeżdża w kierunku zachodzącego słońca przy akompaniamencie kiczowatej piosenki Roya Orbisona, podobno dodana wbrew intencjom Antonioniego ${ }^{20}$, nie wydaje się nie na miejscu, nie tylko z tego względu, że stanowi antidotum na fascynację wywołaną przez obrazy eksplozji. Ostatnie ujęcie jawi się jako pozbawione znaczenia nie tylko dlatego, że jest banalne, ale ponieważ już je gdzieś widzieliśmy. Gdy Mark wysiada z autobusu w Hawthorne, widzimy billboard zajmujący większość ekranu, który ukazuje, jak ostatnia scena Zabriskie Point, słońce zachodzące za górami na pustyni. Jest na nim napis: Są rzeczy, na których możesz polegać. Bank of America. W zatomizowanym świecie bezsensownej fascynacji pozostaje tylko to.

SŁAWOMIR MASŁOŃ

${ }^{1}$ R. W. Emerson, Essays and Lectures, The Library of America, New York 1983, s. 206.

${ }^{2}$ A. Restivo, Revisiting ,Zabriskie Point”, w: Antonioni: Centenary Essays, red. L. Rascaroli, J. D. Rhodes, BFI/Palgrave Macmillan, London 2011, s. 89.

${ }^{3}$ M. Pomerance, Michelangelo Red Antonioni Blue: Eight Reflections on Cinema, University of California Press, Berkeley 2011, s. 190.

4 Klasyczną analizą tej fantazji jest praca L. Marx, The Machine in the Garden: Technology and the Pastoral Ideal in America, Oxford University Press, Oxford 2000, po raz pierwszy opublikowana w $1964 \mathrm{r}$.

${ }^{5}$ T. Jefferson, Uwagi o państwie Wirginia, tłum. T. Wieciech, Księgarnia Akademicka, Kraków 2014, s. 220-221.

${ }^{6}$ L. Marx, dz. cyt., s. 127-128.

${ }^{7}$ M. Pomerance, dz. cyt., s. 192.

${ }^{8}$ Joan Copjec dogłębnie i szczegółowo analizuje pojęcia zszytej (sutured) i nie-zszytej (non-sutured) przestrzeni na przykładzie filmu noir w Locked Room/Lonely Room: Private Space in Film Noir, w: J. Copjec, Read My Desire: Lacan Against the Historicists, The MIT Press, Cambridge 1994, s. 163-200.

${ }^{9}$ Tamże, s. 90-96.

${ }^{10} \mathrm{~W}$. Arrowsmith, Antonioni: The Poet of Images, red. T. Perry, Oxford University Press, Oxford 1995, s. 128-129.
${ }^{11}$ M. Pomerance, dz. cyt., s. 159. Część tej historii, która obejmowała również spekulacje gruntami, jest przedstawiona w Chinatown (Roman Polański, 1974).

${ }^{12}$ M. Pomerance, dz. cyt., s. 188.

${ }^{13}$ Klasyczne omówienie tego tematu to praca R. F. Nash, The Wilderness and the American Mind, Yale University Press, New Haven 2014, której pierwsze wydanie opublikowano w $1967 \mathrm{r}$.

${ }^{14}$ E. Abbey, Desert Solitaire, The University of Arizona Press, Tuscon 1988, s. 39; podkreślenie dodane.

${ }^{15}$ Tamże, s. 41.

${ }^{16}$ Tamże, s. 6.

${ }^{17}$ Co masz na myśli, mówiąc, że maja odjazd na punkcie rzeczywistości (reality trip)? - Daria pyta Marka o jego przyjaciół. - No tak, nie potrafia sobie wyobrazić rożnych rzeczy - odpowiada sama sobie.

${ }^{18}$ A. Restivo, dz. cyt., s. 95.

19 Jedyną czynnością, która idzie w parze z całkowitą fascynacją, jest natręctwo powtarzania - trzynaście eksplozji budynku jest tego przeczuciem.

${ }^{20}$ W. Arrowsmith, dz. cyt., s. 146 i 186. 